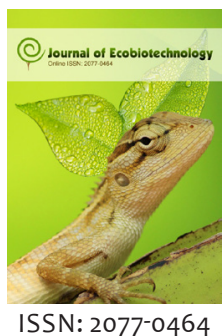

Received: February 28, 2019

Accepted: April 08, 2019

Published: April 10, 2019

*Corresponding Author:

A. E. Sharief

Email: shariefali42@gmail.

com

\section{Individual and combined effects of antioxidant and salinity on germination characters of rice}

\author{
A. A. Kandil', A. E. Sharief'*, Fatma M. Abd EL-Fatah² \\ 'Department of Agronomy, Faculty of Agriculture, Mansoura University, Egypt, ${ }^{2}$ Central Administration for Seed \\ certification (CASC), Ministry of Agriculture, Egypt.
}

\begin{abstract}
A germination experiment was carried out in rice to study the role played by various antioxidants on germination parameters under salt stress in some rice cultivars. The results indicated that the highest germination percentage, rate (days), index and speed were recorded in Sakha 106 cultivar. An increase in the concentration of salt from 100 $\mathrm{mM}$ to $300 \mathrm{mM}$ resulted in a reduction in these parameters. Pretreatment of the seeds with Humic acid at 500ppm increased these studied parameters. All studied characters were affected by the interaction between rice cultivars, salinity concentrations and antioxidants. In general, the study suggested that antioxidant pretreatment in rice seeds can be considered as a potential tool to enhance germination parameters under salinity stress, especially in rice Sakha 106 cultivars.
\end{abstract}

KEYWORDS: Rice cultivars, antioxidants, salinity levels, germination parameters

\section{INTRODUCTION}

Rice (Oryza sativa L.) is one among the widely cultivated and used cereal crops in the world. The cultivation of rice is greatly inhibited by salinity in Egypt [1]. Salinity is a serious threat to rice production in North Delta, Egypt. To increase grain yield production of rice through cultivating modern rice cultivars in new reclaimed soil, which suffers from salinity also, clay soil as old soil gains salinity from irrigation salinity water and with drought [2].

There are numerous studies about salinity tolerance and mechanisms in many plants and also in rice cultivars [3-8]. Treatments of seeds of Giza 177 and Sakha 103 cultivars with salicylic or ascorbic acid induced one Esterase3 isoenzymes. Pre-sowing rice seed of Sakha 104 cultivar with Ascorbic produced the highest germination percentage, speed germination index and germination rate compared with other two cultivars under salinity condition [9].

There are reports about increased proline and antioxidant metabolism under salinity, which confers salinity tolerance to the plants [10-12]. The present study undertaken with the aim to study the role played by various antioxidant components in the salt tolerance mechanism of some rice cultivars.

\section{MATERIALS AND METHODS}

\section{Treatments and Experimental Design}

A laboratory experiment conducted in the Giza Central Seed Testing Laboratory of Central Administration for Seed Certification (CASC), Ministry of Agriculture Egypt during May and June 2017, , to study the response of antioxidants seed prim of some bread wheat cultivars to germinate under salinity levels. A factorial experiment in Randomized Complete Block Design in four replication used. The five rice cultivars, Giza 178, Egyptian Hybrid 1, Sakha 101, Sakha 104 and Sakha 106 cultivars include the first factor. The second factor includes the four salinity levels $0,100,200$ and $300 \mathrm{mM}$. The four types of antioxidants, Salicylic acid $100 \mathrm{ppm}$, Folic acid $15 \mathrm{mM}$, Ascorbic acid 100 PPM and Humic acid 500 PPM includes the third factor. Selected cultivars obtained from Rice Research Institute at Sakha, ARC, Ministry of Agriculture, Egypt.

The germination parameters like final germination percentage, germination rate, germination index and energy of germination were estimated by following standard methods [13-16].

\section{Statistical Analysis}

The data collected were analyzed, statistically by the analysis of variance technique using the MSTAT-C statistical package

Copyright: $\odot$ The authors. This article is open access and licensed under the terms of the Creative Commons Attribution License (http://creativecommons.org/licenses/by/4.0/) which permits unrestricted, use, distribution and reproduction in any medium, or format for any purpose, even commercially provided the work is properly cited. Attribution - You must give appropriate credit, provide a link to the license, and indicate if changes were made. 
as described [17]. Lest significant differences test (LSD) for 5 $\%$ level of probability used for comparisons between treatment means [18].

\section{RESULTS AND DISCUSSION}

\section{Cultivar Performance}

Results in Table 1 showed that studied rice (Oryza sativa L.) cultivars significantly affected the germination parameters. Sakhal06 cultivar surpassed other cultivars in averages of final germination percentage, germination rate, germination index and germination speed. While, Sakhal04 cultivar showed the least values. The highest final germination percentage in Sakhal06 cultivar it was $89.77 \%$ while the lowest in Sakha 104 cultivar it was $71.60 \%$. It could be noticed that, Sakhal06 cultivar surpassed Egyptian hybrid 1, Giza 178, Sakha 101 and Sakha 104 cultivars in final germination percentage by $15.41,17.57,18.76$ and $20.24 \%$ respectively. Highest Germination rate was in Sakhal06 cultivar it was $3.68 \%$ while the lowest was in Sakha 104 cultivar it was $2.82 \%$. It could be observed that, Sakhal06 cultivar surpassed Giza 178, Egyptian hybridl, Sakha 10 land Sakha 104 by $15.76,16.30,20.38$ and $23.36 \%$, respectively. There were significant differences in germination index among all studied cultivars. The highest germination index, which was $92.26 \%$ in Sakhal06 cultivar, while, the lowest germination index was $81.60 \%$ in Sakha 104. Sakhal 06 cultivar surpassed, Egyptian hybrid1, Sakha 101, Giza 178, and Sakha 104 cultivars in germination index by $6.48,11.46,11.52$ and $11.55 \%$, respectively. The results showed that there were significant differences due to Cultivars in germination speed. Sakha 106 recorded the highest germination speed, which was $47.20 \%$. \%. While, the lowest germination speed was obtained from Sakha 104, which was 41.27\%. Sakha 106 cultivar surpassed Giza 178, Sakhal01, Egyptian Hybrid1, and Sakhal01cultivars in germination speed by 9.59, 10.52, 11.02 and $12.56 \%$, respectively. Similar conclusion was obtained from results of [19-22].

\section{Salinity Stress Effects}

Table 2 shows that salt level significantly affected final germination percentage, germination rate, germination index and germination speed in rice cultivars. Our results are in accordance with previous studies $[23,24,25,26]$.

\section{Antioxidants Effects}

Table 3 shows the results of final germination percentage in rice under treatment with antioxidants. Humic acid, Ascorbic acid, Folic acid and Salicylic acid significantly exceeded which were $80.87,78.13,76.74$ and 71 , respectively when compared with the control, which was 77.77 . It could be noticed that, humic acid surpassed Ascorbic acid, control, Folic acid and Salicylic acid in final germination percentage by $3.38,3.83,5.44$ and $12.20 \%$ respectively. Humic acid, Ascorbic acid, Folic acid and Salicylic acid significantly exceeded significant differences between them, which were $3.27,3.23,3.20$ and $2.92 \%$, respectively compared with the control, which was $2.99 \%$. It could be observed that humic acid surpassed Ascorbic acid, Folic acid, control and Salicylic acid in germination rate by 1.22, 2.14, 8.56 and $11.98 \%$, respectively. Results indicated that, there were significant differences in germination speed between humic acid, Ascorbic acid, Folic acid, and Salicylic acid. Significantly exceeded which were $45.67,44.33,43.80$ and 41.00 respectively compared with the control, which was 39.57 . It could be noticed that humic acid surpassed Ascorbic acid Folic acid, and Salicylic acid compared with the control treatment in germination speed by $2.93,4.09,10.22$ and $13.35 \%$, respectively. These responses are in accordance with previous studies [27-30].

\section{Interaction Effects}

\section{Interaction between cultivars and salinity effect}

With respect to the interaction effects data illustrated in Figures 1-4 clearly showed that germination parameters were significantly affected by the interaction between studied cultivars and salinity. our results are in agreement with previous studies [31-34].

\section{Interaction between cultivars and antioxidant effect}

With respect to the interactions between antioxidants and cultivars in Figures 5-8 clearly showed that final germination percentage, germination rate, germination index and germination speed were significantly affected by the interaction between studied cultivars and antioxidant. The highest germination speed was produced from Sakha 106 cultivar, which was 49.00 and 47.67 , respectively with pretreatment by Ascorbic acid at $100 \mathrm{ppm}$ and humic acid at $500 \mathrm{ppm}$, compared with the control treatment. It could be stated that Sakha 106 cultivar surpassed in these

Table 1: Variations in final germination percentage \%, Germination rate, Germination index (\%) and Germination speed (\%) among rice cultivars

\begin{tabular}{|c|c|c|c|c|}
\hline $\begin{array}{l}\text { Characters } \\
\text { Treatments }\end{array}$ & Final germination percentage (\%) & Germination rate (days) (\%) & Germination index (\%) & Germination speed (\%) \\
\hline \multicolumn{5}{|l|}{ A- Cultivars } \\
\hline Giza 178 & 74.00 & 3.10 & 81.63 & 42.67 \\
\hline Egyptian Hybrid 1 & 75.93 & 3.08 & 86.28 & 42.00 \\
\hline Sakha 101 & 72.93 & 2.93 & 81.68 & 42.23 \\
\hline Sakha 104 & 71.60 & 2.82 & 81.60 & 41.27 \\
\hline Sakha 106 & 89.77 & 3.68 & 92.26 & 47.20 \\
\hline LSD at $5 \%$ & 0.75 & 0.07 & 1.10 & 0.80 \\
\hline
\end{tabular}


paramters under pretreatment by humic acid at $500 \mathrm{ppm}$ and Ascorbic acid at $100 \mathrm{ppm}$ than the other studied cultivars. Similar conclusion was observed by previous researchers [35-38].

Table 2: Effect of increasing salt concentration on germination parameters of rice

Characters Final germination Germination Germination Germination Treatments percentage (\%) rate (days) (\%) index (\%) speed (\%)

\begin{tabular}{lcccc}
\hline B- Salinty levels & & & & \\
$0 \mathrm{mM}$ & 86.45 & 3.46 & 95.59 & 49.33 \\
$100 \mathrm{mM}$ & 82.56 & 3.18 & 91.27 & 44.24 \\
$200 \mathrm{mM}$ & 72.99 & 3.13 & 80.59 & 41.33 \\
$300 \mathrm{mM}$ & 65.39 & 2.72 & 72.17 & 37.39 \\
LSD at 5\% & 0.67 & 0.06 & 0.35 & 0.71 \\
\hline
\end{tabular}

Interaction between antioxidants types and salinity levels effect

Means of, the interactions between Salinity and Antioxidants as shown in Figure. 9 showed that the interactions between Salinity and Antioxidants significantly affected final germination percentage. The results clearly indicated that highest final germination percentage was in control treatments and $0 \mathrm{mM}$ salinity it was $90.4 \%$, increasing salinity levels from 100, 200 and $300 \mathrm{mM}$ of $\mathrm{NaCl}$ reduced final germination percentages by $82.13,73.47$ and 65.07 respectively. The others antioxidants as humic acid at $500 \mathrm{ppm}$, Ascorbic acid at $100 \mathrm{ppm}$, Folic acid at $15 \mathrm{mM}$ and Salicylic acid at $100 \mathrm{ppm}$. It could be observed that, all Antioxidants under salinity levels as 100, 200 and 300

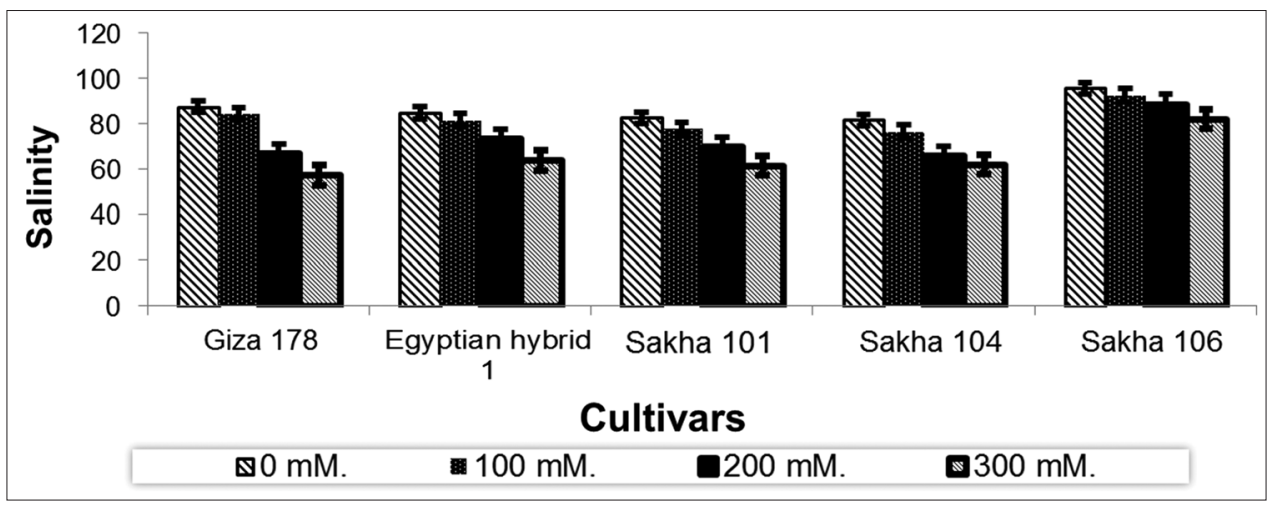

Figure 1: Percentage of final germination as affected by the interaction between cultivars and salinity levels of $\mathrm{NaCL}$.

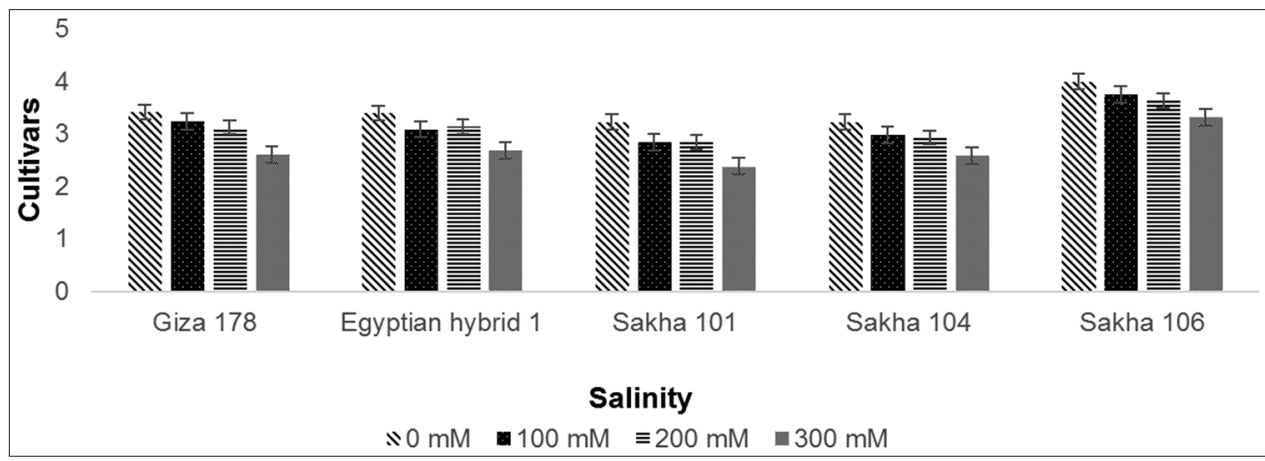

Figure 2: Means of germination rate \% for the interactions between cultivars and salinity levels of $\mathrm{NaCL}$.

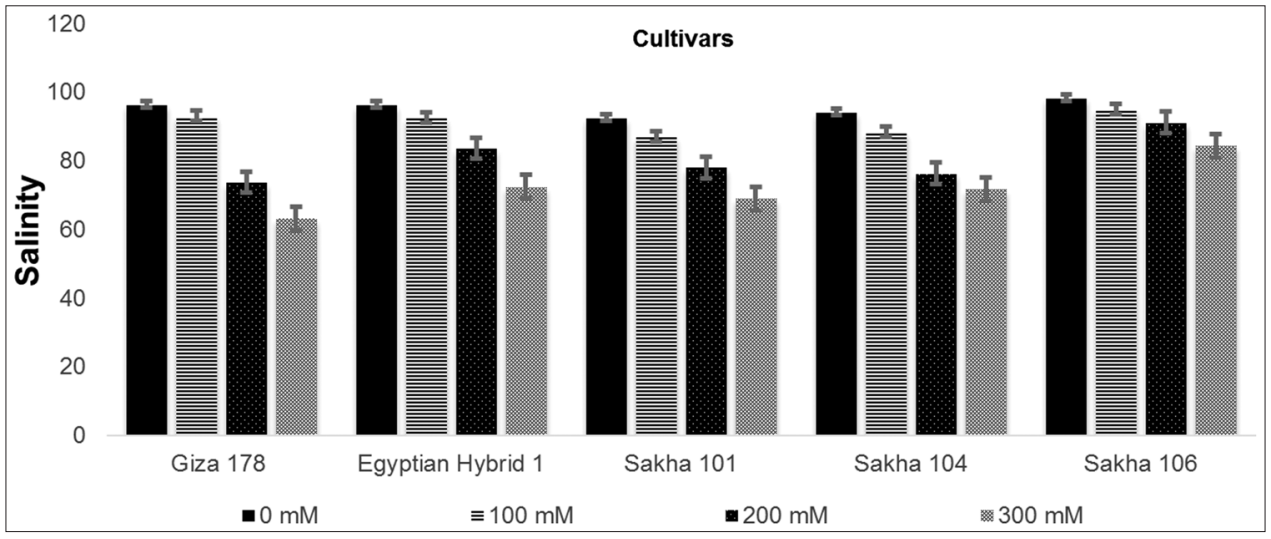

Figure 3: Means of germination index \% for the interactions between cultivars and salinity levels of $\mathrm{NaCL}$. 
Table 3: Effect of antioxidants concentration on germination parameters of rice

\begin{tabular}{|c|c|c|c|c|}
\hline $\begin{array}{l}\text { Characters } \\
\text { Treatments }\end{array}$ & Final germination $\%$ & Germination rate (days) (\%) & Germination index (\%) & Germination speed (\%) \\
\hline \multicolumn{5}{|l|}{ C-Antioxidants } \\
\hline Control & 77.77 & 2.99 & 85.92 & 39.57 \\
\hline Humic acid at $500 \mathrm{ppm}$ & 80.87 & 3.27 & 89.36 & 45.67 \\
\hline Ascorbic acid at $100 \mathrm{ppm}$ & 78.13 & 3.23 & 86.34 & 44.33 \\
\hline Folic acid at $15 \mathrm{mM}$ & 76.47 & 3.20 & 84.51 & 43.80 \\
\hline Salicylic acid at $100 \mathrm{ppm}$ & 71.00 & 2.92 & 78.39 & 41.00 \\
\hline LSD at $5 \%$ & 0.75 & 0.07 & 1.10 & 0.80 \\
\hline
\end{tabular}

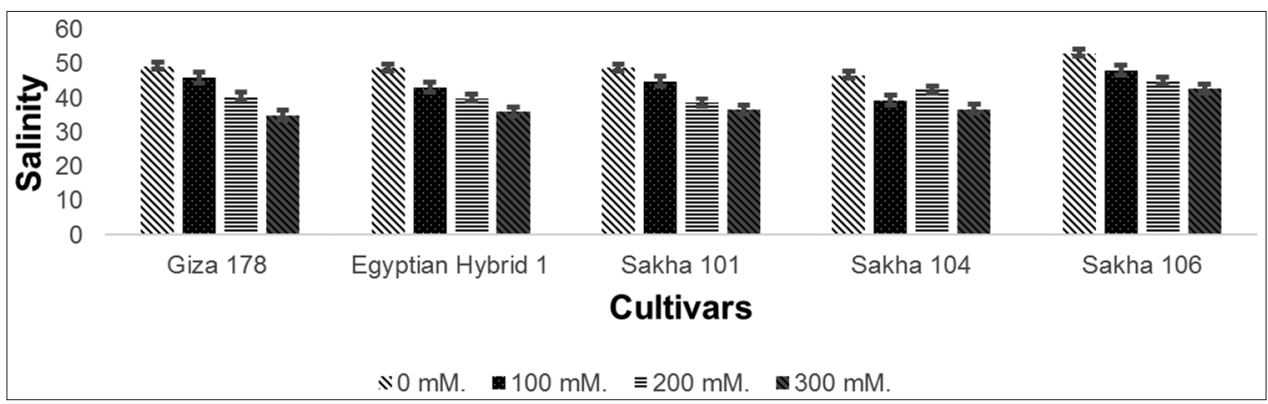

Figure 4: Means of germination speed \% for the interactions between Cultivars and Salinity levels of NaCL.

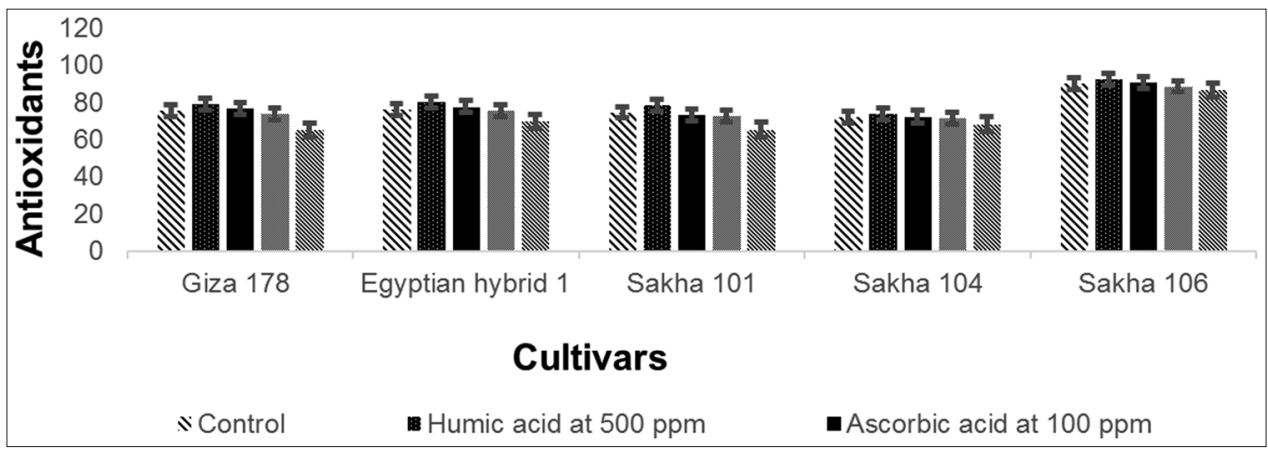

Figure 5: Means of final germination percentage \% for the interactions between cultivars and antioxidants concentrations.

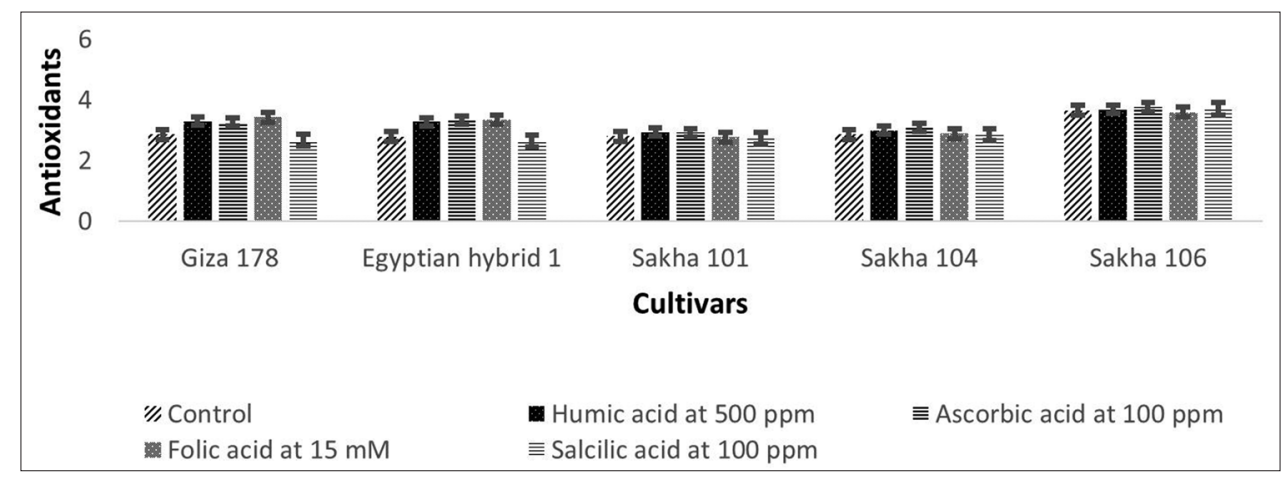

Figure 6: Means of germination rate \% for the interactions between cultivars and antioxidants concentrations.

highest results than the control treatments. These results are in agreement with those reported [39-43].

With respect to, the interactions between Salinity and Antioxidants as shown in Figure. 11 showed that the interactions between Salinity and Antioxidants significantly affected germination index. The results clearly indicated that highest germination index in Humic acid at $500 \mathrm{ppm}$ was in $0 \mathrm{mM}$ of salinity it was $99.10 \%$, increasing salinity levels from 100, 200 and $300 \mathrm{mM}$ of $\mathrm{NaCl}$ reduced germination index the lowest was 64.73 in Salicylic acid at $100 \mathrm{ppm}$ in $300 \mathrm{mM}$ of NaCl. In this respect, previous study [44] reported that Ascorbic acid is a major primary antioxidant, and Salicylic acid is an endogenous growth regulator of phenolic nature. 
Kandil, et al.

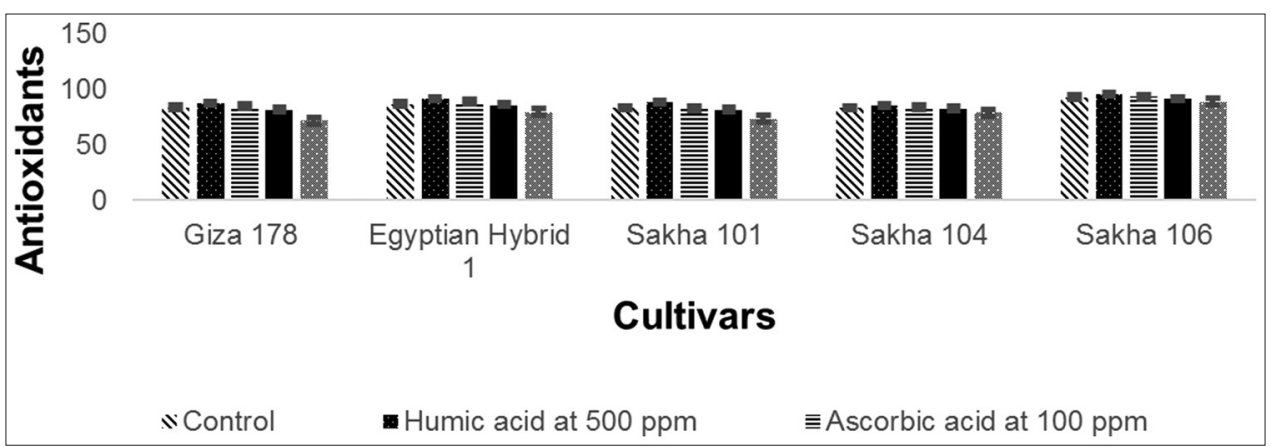

Figure 7: Means of germination index $\%$ for the interactions between cultivars and antioxidants concentrations.

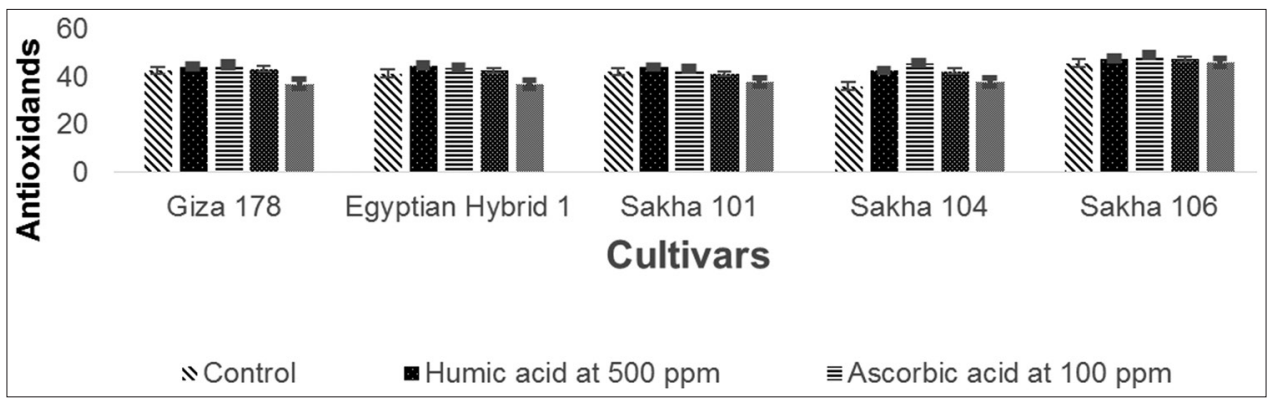

Figure 8: Means of germination speed \% for the interactions between cultivars and antioxidants concentrations.

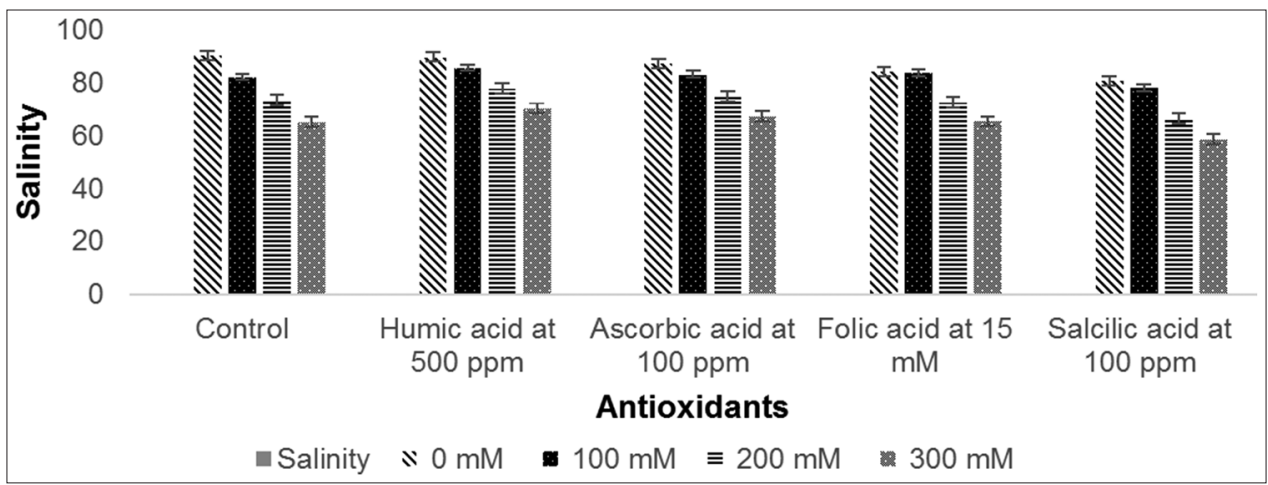

Figure 9: Means of final germination percentage \% for the interactions between salinity levels of $\mathrm{NaCL}$ and antioxidants concentrations.

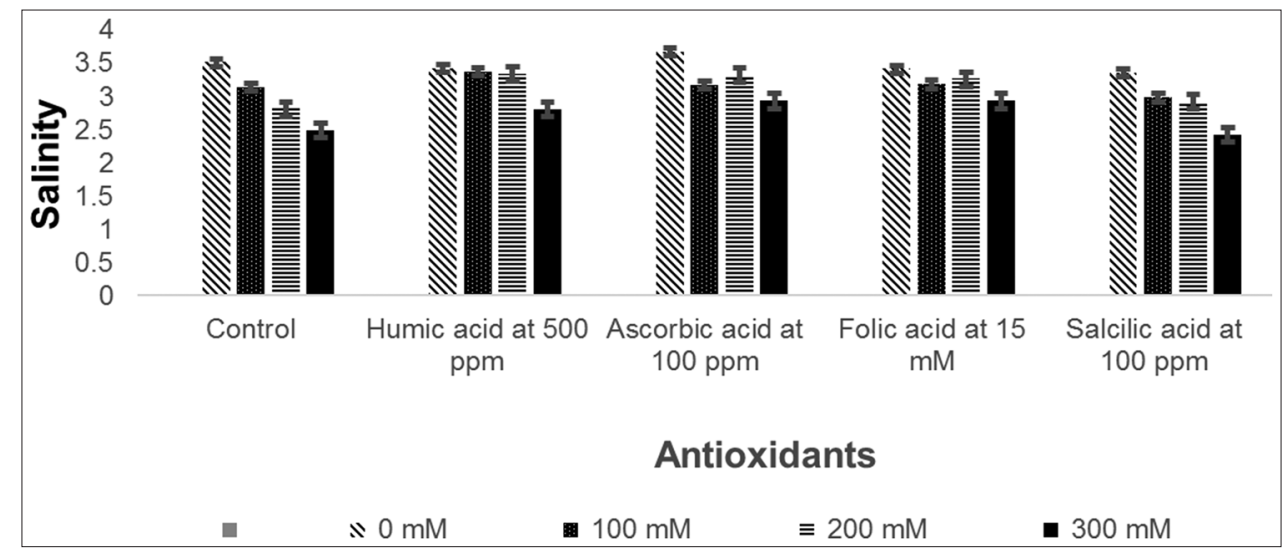

Figure 10: Means of germination rate \% for the interactions between salinity levels of $\mathrm{NaCL}$ and antioxidants concentrations. 


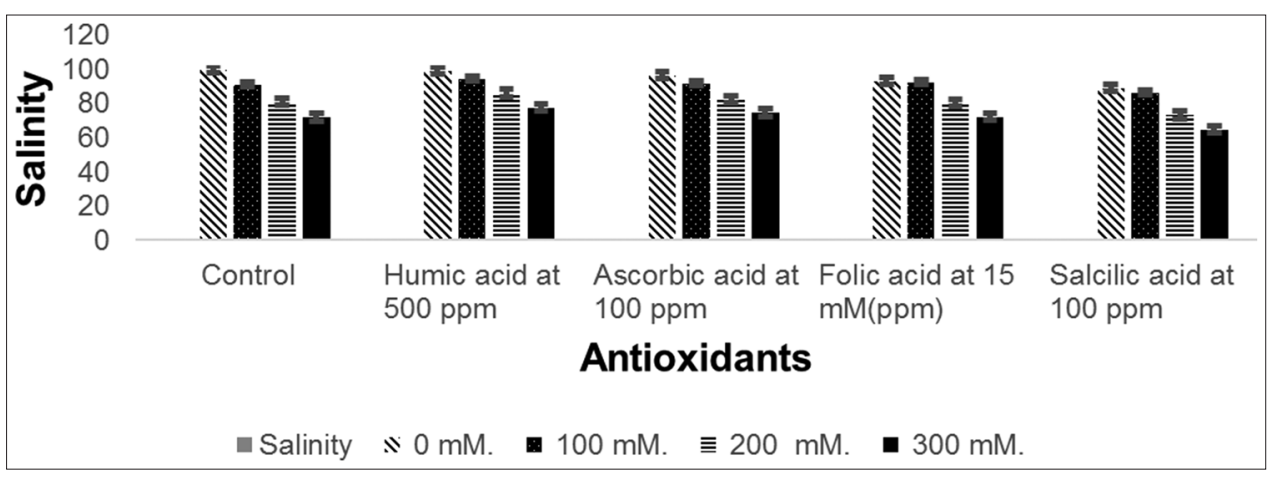

Figure 11: Means of germination index \% for the interactions between salinity levels of $\mathrm{NaCL}$ and antioxidants.

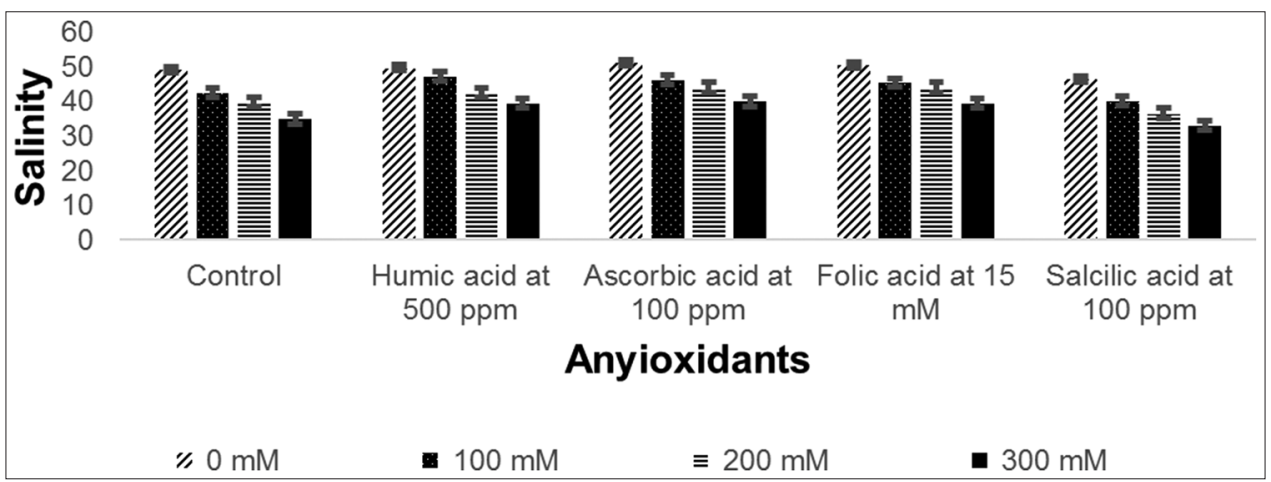

Figure 12: Means of germination speed \% for the interactions between salinity levels of $\mathrm{NaCL}$ and antioxidants concentrations.

\section{CONCLUSION}

Maximizing germination characters of rice under saline soil condition of Egypt, it could be recommended that priming seed of Sakha 106 cultivar in humic acid at concentration of $500 \mathrm{ppm}$ or Ascorbic acid at $100 \mathrm{ppm}$ under salinity stress and used in breeding program for enhancing rice production.

\section{REFERENCES}

1. FAO, 2007. FAO Food and Agriculture Statistics. Agristat, www. fao.org.

2. Hoai NT, Shim IS, Kobayashi K, Kenji U. Accumulation of some nitrogen compounds in response to salt stress and their relationships with salt tolerance in rice (Oryza sativa L.) seedlings. Plant Growth Regulation. 2003;41(2):159-64.

3. Kader MA, Lindberg S. Uptake of sodium in protoplasts of saltsensitive and salt-tolerant cultivars of rice, Oryza sativa L. Determined by the fluorescent dye SBFI. Journal of Experimental Botany. 2005;56:3149-3158.

4. Moradi F, Ismail AM. Responses of Photosynthesis, Chlorophyll Fluorescence and ROS-Scavenging Systems to Salt Stress during Seedling and Reproductive Stages in Rice. Annals of Botany. 2007:99(6):1161-1173.

5. Balakrishna M, Shukla YM. Effects of Salinity Stress on Antioxidant Enzyme Activity Levels in Rice Cultivars. Asian Journal of Microbiology, Biotechnology \& Environmental Sciences Paper. 2009; 11(1):49-53.

6. Kader MA, Lindberg S. Cytosolic calcium and pH signaling in plants under salinity stress. Plant signaling \& behavior. 2010;5(3):233-8.

7. Roychoudhury A, Basub S, Sengupta DN. Amelioration of salinity stress by exogenously applied spermidine or spermine in three varieties of Indica rice differing in their level of salt tolerance. Journal of Plant Physiology. 2011;168:317-328.
8. El-Manzlawy AM, Ibrahim AEA. Influence of antioxidants pre-sowing on biochemical and seed vigor of some rice (Oryza sativa L.) varieties under salinity. Journal of Plant Production, Mansoura University. 2011;2(7):871-881.

9. Kibria M G, Hossain M, Murata Y. Hoque MdA. Antioxidant Defense Mechanisms of Salinity Tolerance in Rice Genotypes. Rice Science. 2017;24(3): 155-162.

10. Sohn YG, Lee BH, Kang KY, Lee IJ. Effects of $\mathrm{NaCl}$ Stress on Germination, Antioxidant Responses, and Proline Content in Two Rice Cultivars. Journal of Plant Biology. 2005;48(2):201-208.

11. Ashraf M, Foolad MR. Roles of glycinebetaine and proline in improving plant abiotic stress resistance. Environmental and Experimental Botany. 2007;59:206-216.

12. Turan S, Tripathy BC. Salt and Genotype Impact on Antioxidative Enzymes and Lipid Peroxidation in Two Rice Cultivars during deterioration. Protoplasma An International Journal of Cell Biology. 2012;250(1):209-222.

13. ISTA, International seed testing association. ISTA, 2016; Germination Sec. Chapter 19: pp. 19-41.

14. Ellis RA, Roberts EH. The quantification of ageing and survival in orthodox seeds. Seed Science Technology. 1981;9: 373-409.

15. Ruan S, Xue Q, Tylkowska K. Effects of seed priming on germination and health of rice Oryza sativa L. seeds. Seed Science and Technology. 2002;30:451-458.

16. Karim MA, Utsunomiya N, Shigenaga S. Effect of sodium chloride on germination and growth of hexaploid triticale at early seedling stage. Japanese Journal of Crop Science. 1992;61:279-284.

17. Gomez KA, Gomez AA. Statistical Procedures in Agricultural Research John Wiley and Sons, 1991; New York.

18. Snedecor GW, Cochran WG. Statistical Methods. $7^{\text {th }}$ Ed. lowa State University Press, lowa, USA. 1980; ISBN-10: 0-81381560-6, Pp: 507.

19. Kumar V, Shriram V, Jawali N, Shitole MG. Differential response of Indica Rice genotypes to $\mathrm{NaCl}$ stress in relation to physiological and biochemical parameters. Archives of Agronomy and Soil Sci. 2007; 53(5):581-592.

20. Moud AM, Maghsoudi K. Salt stress effects on respiration and growth of germinated seeds of different wheat (Triticum aestivum L.) 
cultivars. World Journal of Agricultural Science. 2008:4(3):351-8.

21. Golshani M, Pirdashti H, Saeb K, Babakhani B, Heidarzade A. Response of seed germination and seedling emergence of Rice (Oryza sativa L.) genotypes to different osmopriming levels. World Applied Science Journal. 2010;9(2):221-225.

22. Islam MM, Karim MA. Evaluation of Rice Oryza sativa L. genotypes at germination and early seedling stage for their tolerance to salinity. The Agriculture. 2010; 8 (2):57-65.

23. Rahman MS, Miyake H, Takeoka Y. Effect of sodium chloride salinity on seed germination and early seedling growth of Rice (Oryza sativa L.). Pakistan Journal of Biological Science. 2001;4(3):351-355.

24. Khan AS, Asad MA, Ali Z. Assessment of genetic variability for $\mathrm{NaCl}$ tolerance in wheat. Pakistan Journal of Agricultural Science. 2003;40(1):33-6.

25. Alam MZ, Bhuiya AA, Muttaleb MA, Rashid MM. Effect of alternating saline and non-Saline conditions on emergence and seedling growth of Rice. Pakistan Journal of Biological Science. 2004;7(6):883-890.

26. Hakim MA, Juraimi AS, Begum M, Hanafi MM, Ismail MR, Selamat A. Effect of salt stress on germination and early seedling growth of Rice (Oryza sativa L.). African Journal of Biotechnology. 2010;9(13):1911-1918.

27. Kandil AA, Sharief AE, and Alkhamsa K, Botabaah D. Evaluation of some wheat genotypes to salt tolerance under antioxidant using physiological indices. International Journal of Agricultural Policy and Research. 2018;6(4):38-49

28. Flowers TJ, Yeo AR. 1981. Variability in the resistance of sodium chloride salinity within Rice (Oryza sativa L.) varieties. New Phytologist. 1981;88:363-373.

29. Tsai YC, Hong CY, Liu LF, Kao CH. Relative importance of $\mathrm{Na}+$ and $\mathrm{Cl}-$ in $\mathrm{NaCl}$-induced antioxidant systems in roots of rice seedlings. Physiol. Plant. 2004;122: 86-94.

30. Akbari G, Sanavy SAMM, Yousef Zadeh S. Effect of Auxin and salt stress $(\mathrm{Na} \mathrm{Cl})$ on seed germination of Wheat cultivars (Triticum aestivum L.). Pakistan Journal of Biological Science. 2007; 10:2557-2561

31. Jamil M, Rha, ES. Response of transgenic Rice at germination and early seedling growth under salt stress. Pakistan Journal of Biological Science. 2007; 10:4303-4306

32. El-Tayeb MA. Response of barley grains to the interactive effect of salinity and salicylic acid Plant Growth Regulation. 2005;45:215-224.
33. Emam MM, Helal NM. Vitamins minimize the salt-induced oxidative stress hazards Australian Journal of Basic and Applied Sciences. 2008; 2(4): 1110-1119.

35. Amin AA, EI-Kader AA, Shalaby MA, Gharib FA, Rashad ES, Teixeira da Silva JA. Physiological effects of salicylic acid and thiourea on growth and productivity of maize plants in sandy soil. Communications in Soil Science and Plant Analysis. 2013 Apr 12;44(7):1141-55.

36. Khafagy MA, Darowish MM, Salama SM, Abo-El-Kheer EAM. Effect Of Water Priming duration on Rice (Oryza sativa L.) Germination and seedling growth under iso-osmotic solutions of Nacl and PEG. Journa of Plant Production, Mansoura University. 2014;5(12):2141 -2157.

37. Lee KS, Choi WY, Kom JC, Kim TS, Gregorio GB. Salinity tolerance of Japonica and Indica Rice Oryza sativa L. at the seedling stage. Planta. 2003;216:1043-1046

38. Kazem M, Foliar application of salicylic acid and calcium on yield, yield component and chemical properties of strawberry. Bulletin of Environment, Pharmacology and Life Sciences. 2013;2:19-23.

39. Fahad S, Bano A. Effect of salicylic acid on physiological and biochemical characterization of maize grown in saline area Pakistan Journal of Botany. 2014;44(4):1433-1438.

40. Mervat SH, Sadak, M, Abdelhamid T, Urs S. Effect of foliar application of aminoacids on plant yield and some physiological parameters in bean plants irrigated with seawater. Acta Biologica Colombiana. 2014;20(1):141-152.

41. Ibrahim MFM, Abd El-Gawad HGM, Bondok A. Physiological impacts of potassium citrate and folic acid on growth, yield and some viral diseases of potato plants. Middle East Journal of Agriculture Research. 2015;04(03):577-589.

42. Faten SA, Shaheen AM., Ahmed AA, Asmaa RM. Effect of Foliar Application of Urea and Amino Acids Mixtures as Antioxidants on Growth, Yield and Characteristics of Squash. Research Journal of Agriculture and Biological Sciences. 2010;6(5):583-588.

43. Yousof FI, Mersal IF, EL-Emam AAM. Effect of soaking rice Oryza sativa, L. seed in some anitioxidants solutions on germination and seedling vigor under different salinity levels. Journal of Plant Production. 2010;1(2):279 - 290.

44. Maryam A, Faghami E. Role of salicylic acid and ascorbic acid in the alleviation of salinity stress in wheat (Triticum aestivum L.). Journal of Biodiversity and Environmental Sciences. 2015;6(2):107-113. 